\title{
Inhibition of bone turnover by milk intake in postmenopausal women
}

\author{
Jean-Philippe Bonjour ${ }^{1 *}$, Marion Brandolini-Bunlon ${ }^{2}$, Yves Boirie $^{2}$, Françoise Morel-Laporte ${ }^{2}$, \\ Véronique Braesco ${ }^{2}$, Marie-Claude Bertière ${ }^{3}$ and Jean-Claude Souberbielle ${ }^{4}$ \\ ${ }^{1}$ Service of Bone Diseases, University Hospital, Rue Micheli-Du-Crest, Geneva 1211, Switzerland \\ ${ }^{2}$ Centre de Recherche en Nutrition Humaine d'Auvergne, 58 rue Montalembert, 63009 Clermont-Ferrand, France \\ ${ }^{3}$ Centre de Recherche et d'Information Nutritionnelles, 45 rue Saint-Lazare, 75314 Paris, France \\ ${ }^{4}$ Laboratoire d'Explorations Fonctionnelles, Hôpital Necker-Enfants Malades, 149 rue de Sèvres, 75015 Paris, France
}

(Received 22 August 2007 - Revised 19 December 2007 - Accepted 21 January 2008 - First published online 26 February 2008)

\begin{abstract}
Increased postmenopausal bone turnover leads to bone loss and fragility fracture risk. In the absence of osteoporosis, risk preventive measures, particularly those modifying nutritional lifestyle, are appropriate. We tested the hypothesis that milk supplementation affects bone turnover related to biochemical markers in a direction that, in the long term, may be expected to reduce postmenopausal bone loss. Thirty healthy postmenopausal women aged 59.3 (SD 3.3) years were enrolled in a prospective crossover trial of 16 weeks. After a 4-week period of adaptation with diet providing $600 \mathrm{mg}$ calcium plus $300 \mathrm{mg}$ ingested as $250 \mathrm{ml}$ semi-skimmed milk, participants were maintained during 6 weeks under the same $600 \mathrm{mg}$ calcium diet and randomized to receive either $500 \mathrm{ml}$ semi-skimmed milk, thus providing a total of $1200 \mathrm{mg}$ calcium, or no milk supplement. In the next 6 weeks they were switched to the alternative regimen. At the end of the each period, i.e. after 4, 10 and 16 weeks, blood and urinary samples were collected. The changes in blood variables between the periods of 6 weeks without and with milk supplementation were: for parathyroid hormone, $-3.2 \mathrm{pg} / \mathrm{ml}(P=0.0054)$; for crosslinked telopeptide of type I collagen, $-624 \mathrm{pg} / \mathrm{ml}(P<0.0001)$; for propeptide of type I procollagen, $-5.5 \mathrm{ng} / \mathrm{ml}$ $(P=0.0092)$; for osteocalcin, $-2 \cdot 8 \mathrm{ng} / \mathrm{ml}(P=0.0014)$. In conclusion, a 6-week period of milk supplementation induced a decrease in several biochemical variables compatible with diminished bone turnover mediated by reduction in parathyroid hormone secretion. This nutritional approach to postmenopausal alteration in bone metabolism may be a valuable measure in the primary prevention of osteoporosis.
\end{abstract}

Menopause: Milk supplementation: Calcium intake: Bone turnover

Increased bone turnover after menopause is considered a key mechanism in bone loss and increased risk of fragility fracture $^{(1,2)}$. In the general population pharmaceutical intervention aimed at preventing bone loss is no longer widely recommended within the 10-year period following menopause. The reasons for this conservative attitude adopted by the medical community stem from both cost-effectiveness analysis and long-term safety of pharmaceutical intervention on skeletal and extra-skeletal functions ${ }^{(3-6)}$. Particularly, the widespread use of hormone replacement therapy has been reconsidered based on the assessment of benefits and harm $^{(7)}$. Although considerable controversy surrounds the use of hormone replacement therapy ${ }^{(8-11)}$, the results of the Women Health Initiative study ${ }^{(12)}$ led to substantial modifications by health care providers in the prescription pattern for the primary prevention of osteoporosis, with rapid reduction in hormone replacement therapy use $\mathrm{e}^{(13-15)}$. Thus what was considered as the best therapeutic approach in the primary prevention of postmenopausal osteoporosis was widely discontinued as documented by a $57 \%$ prescription reduction in the USA between 2002 and $2004^{(15)}$. Therefore, it appears timely to reconsider other preventive measures, particularly by exploring strategies aimed at reasonably modifying lifestyle factors that are known to exert a beneficial impact on bone metabolism, such as nutrition and physical activity. Several randomized controlled trials indicate that calcium supplementation associated with a sufficient vitamin D supply reduces postmenopausal or age-related bone loss and fragility fracture ${ }^{(16-21)}$. As for any chronic therapies the effectiveness of pharmaceutical medication can be compromised by poor adherence and/or persistence. Insufficient compliance can be explained by various reasons such as safety concerns, inconvenience of treatment schedule, lack of motivation, and/or drug-related side-effects ${ }^{(22)}$. Low compliance holds true not only for specific anti-osteoporosis drugs such as bisphosphonates or raloxifene, but also for pharmaceutical preparations of calcium salts ${ }^{(22,23)}$. In fact, treatment compliance was particularly poor for calcium \pm vitamin D supplements $^{(22)}$. Furthermore, in a recent review some clinical guidance was given regarding the use of calcium and vitamin $\mathrm{D}$ for the prevention of fragility fracture in the subjects at risk ${ }^{(24)}$. The authors considered that calcium

Abbreviations: aBMD, areal bone mineral density; BAP, bone alkaline phosphatase; BRI, net calcium bone resorption index; CTX, crosslinked telopeptide of type I collagen; IGF, insulin-like growth factor; PINP, propeptide of type I procollagen; PTH, parathyroid hormone; TmPi, tubular inorganic phosphate reabsorption capacity; TRCaI, renal tubular calcium reabsorption index.

* Corresponding author: Professor Jean-Philippe Bonjour, fax +41 223829973, email Jean-Philippe.Bonjour@medecine.unige.ch 
and vitamin D supplements remain medicinal products that have to be prescribed by physicians and other health care providers $^{(24)}$. In subjects without impending risk of osteoporosis, as for instance in postmenopausal women at 5-10 years from the time of menstruation cessation with no particular risk factor for osteoporosis, it appears advantageous to provide calcium by increasing its dietary intake ${ }^{(24)}$. Dairy products have a relatively high calcium content as compared to other usual foods. Furthermore, dairy products also provide protein that is certainly an essential nutrient for bone health ${ }^{(25-28)}$.

The most relevant end-point to demonstrate the efficiency of an intervention in the context of osteoporosis is the prospective recording of fragility fractures. This is an extremely demanding end-point that requires enrolment of several thousands of subjects associated with very longterm follow-up, particularly in the absence of prevalent osteoporosis.

Changes in bone biochemical markers have been shown to predict not only the rate of bone loss, but also the risk of incident fragility fractures ${ }^{(29-34)}$. The early predictive effect of bone turnover inhibition of an intervention reducing hip, non-spine and vertebral fracture appears to be at least as strong as that observed with change in areal bone mineral density (aBMD) ${ }^{(34)}$. Furthermore, this predictive value of bone marker variation on bone loss in postmenopausal women was documented not only with bisphosphonate treatment ${ }^{(32,34)}$ but also with calcium supplementation ${ }^{(33)}$. Note that the magnitude ot the early response of bone remodelling biochemical markers is not tightly related to the degree of fracture risk reduction $^{(30-33)}$.

In the present study we investigated in a group of healthy postmenopausal women, with mean age of 59.5 years, displaying a rather moderate reduction in aBMD as compared to young adult subjects, whether milk supplementation would influence biochemical markers in a way compatible with a reduction in bone turnover.

\section{Materials and methods}

\section{Participants}

Thirty healthy women aged between 55 and 65 years, 5 years or more since menopause, volunteered for being enrolled into a prospective crossover trial of 16 weeks. Personal history and clinical examination warranted that those enrolled did not suffer from any disease and/or were not under medical therapy. None of them had taken hormonalrelated therapy for the prevention of postmenopausal disorders during the last 12 months preceding the entry into the trial; no calcium supplementation; neither antiosteoporotic medication including bisphosphonates, calcitonin, raloxifene, strontium ranelate, vitamin $\mathrm{D}$ derivatives, nor medication suggested to act on bone metabolism such as tibolone, anabolic steroids, dehydroepiandrostereone, ipriflavone and other phytoestrogens, or statins. Inclusion criteria were: BMI ranging between 20 and $27 \mathrm{~kg} / \mathrm{m}^{2}$; plasma concentration of follicle-stimulating hormone above $20 \mathrm{IU} / \mathrm{l}$; absence of osteoporosis as defined by osteodensitometric $\mathrm{T}$-score value of $\leq-2 \cdot 5^{(35)}$, or history of low trauma fracture; absence of milk distaste, intolerance or allergy to cows' milk or other dairy products; stable food consumption habits in the last 3 months; mean spontaneous calcium intake $\geq 600 \mathrm{mg} / \mathrm{d}$, with no more than $400 \mathrm{mg}$ provided by non-dairy products such as fruit, vegetables and/or mineral water; normal haematological and biological status; physical activity between 1.25 and 3.75 according to the questionnaire-based index established by Baecke et al. ${ }^{(36)}$; negative HIV and hepatitis $\mathrm{C}$ virus tests; signed inform consent. The ethical committee of the Auvergne region (France) approved the protocol.

\section{Milk content}

The ultra-heat-treated semi-skimmed milk used in the present study contained per $250 \mathrm{ml}: 300 \mathrm{mg}$ calcium, $481 \mathrm{~kJ}$ (115 kcal), $8 \mathrm{~g}$ proteins, $4 \mathrm{~g}$ lipids, $11.5 \mathrm{~g}$ glucides, no vitamin $\mathrm{D}$.

\section{Study design}

At the beginning of the study an oral dose of $100000 \mathrm{IU}$ vitamin $\mathrm{D}_{3}$ contained in a $2 \mathrm{ml}$ vial (Uvédose ${ }^{\circledR}$, Laboratoire Crinex, France) was taken by all participants. This administration was aimed at avoiding any vitamin D insufficiency during the experimental phase. Then, a 4-week period of adaptation was started with diet providing $600 \mathrm{mg}$ calcium plus $300 \mathrm{mg}$ provided by $250 \mathrm{ml}$ semi-skimmed milk. Then during the next 6 weeks the participants were maintained under the same $600 \mathrm{mg}$ calcium diet and randomized to receive either a supplement of $500 \mathrm{ml}$ semi-skimmed milk, thus providing a total of $1200 \mathrm{mg}$ calcium, or no milk supplement. In a third phase of 6 weeks they were switched to the alternative regimen (Fig. 1). The participants were free to consume the milk supplement at one time or in several portions during the day. During the last $24 \mathrm{~h}$ of the adaptation phase and of each experimental period, i.e. after 4,10 and 16 weeks, the participants were asked to collect their urine. The next morning after voiding the overnight urine, samples of both urine and blood were collected in the fasting state.

Food control. During the 16 weeks of the study, the volunteers had to limit their calcium intake to $600 \mathrm{mg} / \mathrm{d}$. For this purpose, the certified dietitian (M. B.-B.) of the investigating team provided the volunteers with a list of foods not to be consumed because of their high calcium content, as well as a list of dairy products they had to eat daily in precise amounts. Water bottles with very low mineral content were distributed to substitute for more mineralized drinking water.

The nutrient intake was assessed at four occasions: at the time of inclusion into the study; by the end of the adaptation period; by the end of the 6-week period without milk supplementation; by the end of the 6-week period with milk supplementation. Each assessment was made by using the diary method over $7 \mathrm{~d}$, with weighing by the participants of all consumed foods. Furthermore, the recorded dietary data in the diary was validated by an interview of the participants by the certified dietitian involved in the study (M. B.-B.). The food nutrient content was obtained by computer analysis using the software Geni version 6.0 (Micro6 ${ }^{\circledR}$, Villers les Nancy, France). This software is based on the pre-recorded nutrient table from Répertoire Général des Aliments ${ }^{(37)}$. 


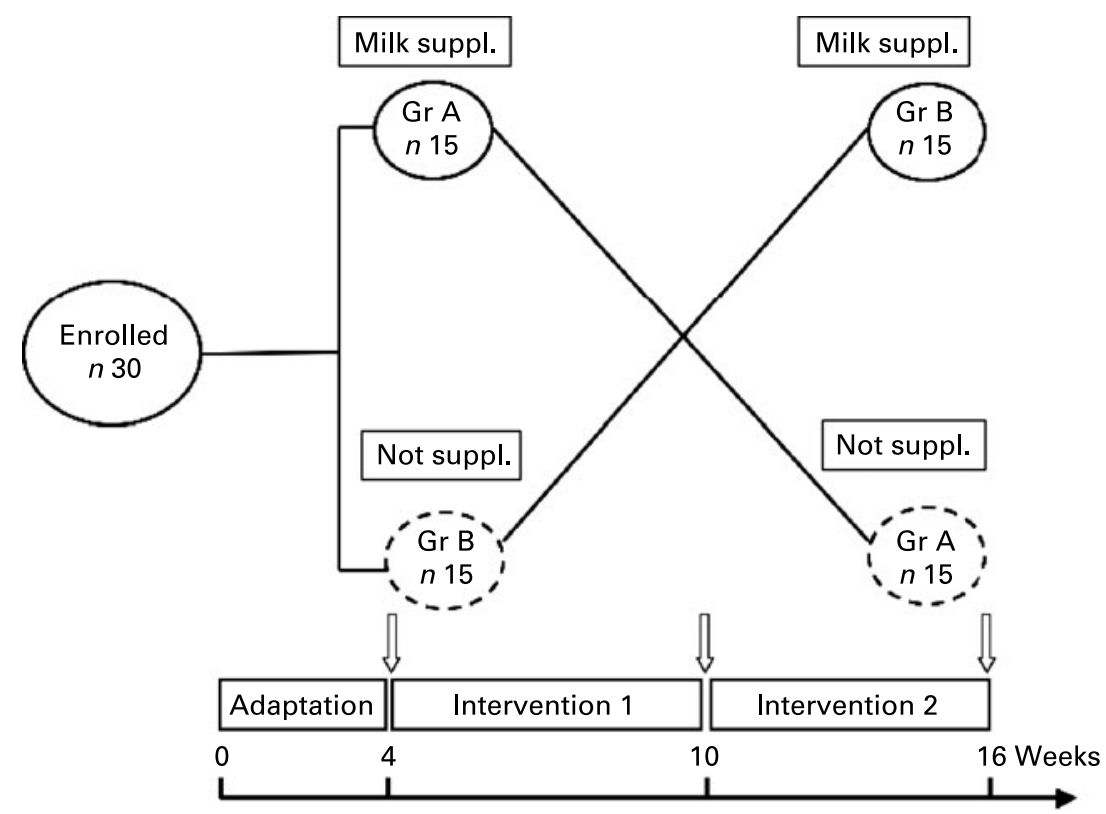

Fig. 1. Experimental protocol: the crossover design was applied to thirty postmenopausal women randomized in two groups (Gr) either with or without milk supplementation (suppl.) during two periods of 6 weeks that were preceded by an adaptation period of 4 weeks. $\downarrow$, Blood and urine samples were collected at the end of the adaptation phase and at the end of each of the two experimental periods.

No instruction aimed at reducing spontaneous intake to avoid weight gain was given to the participants.

The compliance was assessed by both interviewing the participants at the time of checking the data recorded in their diary and by counting the milk bottles which were not consumed.

\section{Biochemical measurements}

As previously reported ${ }^{(38)}$, calcium and magnesium were measured by colorimetry, sodium and potassium by indirect potentiometry with the use of specific electrodes, and creatinine by the Jaffe reaction (Roche Diagnostics, Meylan, France). Serum parathyroid hormone (PTH), osteocalcin, amino-terminal propeptide of type I procollagen (PINP) and carboxy terminal crosslinked telopeptide of type I collagen (CTX; Cross-laps) were measured by automated immunochemiluminescence on the Elecsys platform (Roche Diagnostics) as recently described ${ }^{(39)}$. For these four biochemical analyses the within- and between-run $\mathrm{CV}$ were lower than $5 \%$, whatever the concentration tested. The reference range of these assays was established in a group of fifty-nine premenopausal healthy women aged 35-48 years. All of them had regular menses associated with plasma follicle-stimulating hormone concentration below $12 \mathrm{mU} / \mathrm{l}$. They received a single dose of 100000 IU vitamin $\mathrm{D}_{3} 1$ week before the blood sampling. The reference ranges were $10-46 \mathrm{pg} / \mathrm{ml}$, $13-32 \mathrm{ng} / \mathrm{ml}, 19-50 \mathrm{ng} / \mathrm{ml}$ and $700-3000 \mathrm{pmol} / \mathrm{l}$ for PTH, osteocalcin, PINP and C-telopeptide, respectively. Bone alkaline phosphatase (BAP) was measured by automated immunochemiluminescence on the Access II platform (Beckman-Coulter, Chaska, MN, USA). BAP within-run CV was $6.7 \%$ at mean concentration of $13.2 \mu \mathrm{g} / \mathrm{l}$ and below $5 \%$ at concentration above $25 \mu \mathrm{g} / \mathrm{l}$. The reference range established in healthy premenopausal women was $4-15 \mu \mathrm{g} / \mathrm{l}$. The serum level of 25-hydroxyvitamin $\mathrm{D}$ was measured by RIA (DiaSorin, Stillwater, MN, USA) as previously reported ${ }^{(40)}$.
Vitamin D insufficiency was defined as a serum level of 25 -hydroxyvitamin D lower than $30 \mathrm{ng} / \mathrm{l}^{(41)}$. Serum insulinlike growth factor (IGF) I was measured by an immunoradiometric assay (IGF-I RIA-CT; Schering-Cis Bio, Gif sur Yvette, France) based on the use of two monoclonal antibodies directed toward different IGF I epitopes. In this method, bound IGF I is displaced from IGF binding protein by acidification. A large excess of IGF II is then added to the acid-treated serum to prevent reassociation of IGF I with its carrier proteins when buffer is added. The analytical properties of this assay were recently reported ${ }^{(39)}$. The normal range of serum IGF I in women aged 36-65 years was $77-247 \mathrm{ng} / \mathrm{ml}$.

Indices of the renal reabsorption of either calcium (TRCaI, $\mathrm{mmol} / \mathrm{l}$ glomerular filtration rate) or inorganic phosphate ( $\mathrm{TmPi} / \mathrm{l}$, glomerular filtration rate) were calculated as previously described $^{(42,43)}$ from calcium, inorganic phosphate and creatinine determinations in the plasma and urine samples collected in the fasting state at the end of the intervention periods. Likewise, the estimation of the net release of calcium from bone (BRI, $\mathrm{mmol} / \mathrm{mmol}$ ) was calculated from the ratio of calcium over creatinine urine concentration ${ }^{(43,44)}$. These three indices allow one to discriminate disturbances in calcium-phosphate metabolism that occur in various benign and malign hypercalcaemic diseases $^{(43,44)}$.

\section{Dual X-ray densitometry}

aBMD of the lumbar spine (L2-L4) and femoral neck were measured by dual X-ray absorptiometry on a Hologic QDR 4500 osteodensitometer (Hologic, Massy, France). The determinations were made 3-5 weeks before the enrolment in order to exclude women with osteoporosis, i.e. with T-score $\leq-2.5$ according to the WHO definition ${ }^{(35)}$. The reference range used to calculate $\mathrm{T}$-score values was that provided by the osteodensitometer manufacturer. 


\section{Statistical analysis}

The statistical power was deduced from the expected change in serum CTX that was a priori considered as the main end-point of the study. By using a crossover design, it was expected that a difference would be detected in serum CTX between periods with and without milk supplementation by $20 \%$ with a power of $80 \%$ and a two-sided $\alpha$ of 0.05 . Taking into account a measured intra-individual $\mathrm{CV}$ of $10 \%$, the $20 \%$ difference in serum CTX required a sample of twenty subjects in a crossover-designed study. Thirty subjects were eventually enrolled in order to secure a greater power to the study.

The results are expressed as means and standard deviations in all tables and means and their standard errors in the figure depicting the average of individual differences as expressed in percentage change between the two experimental periods. Paired Student's $t$ test was employed to assess differences between the two periods. Bonferroni's correction was used for the four-biochemical bone remodelling variables, i.e. CTX, PINP, osteocalcin and BAP. $P \leq 0.05$ was considered statistically significant.

\section{Results}

\section{Baseline characteristics}

None of the thirty enrolled women dropped out of the study. They had passed menopause for approximately 9 years (Table 1). Their anthropometric variables (standing height, body weight and BMI) were within the normal range determined in the French women population for that age (Table 1). The oestrogen-deficient status was expressed by the elevation of plasma follicle-stimulating hormone. As expected in non-oestrogensubstituted women at about 9 years from menopause, the osteodensitometric mean $\mathrm{T}$-score values were in the low normal and slightly osteopaenic ranges for the femoral neck and lumbar spine, respectively (Table 1). The blood biochemical markers CTX, PINP, osteocalcin and BAP reflected on the average an increase in bone remodelling as compared to the premenopausal normal ranges (Table 2). All subjects had a serum level of 25 -hydroxyvitamin $\mathrm{D}>20 \mathrm{ng} / \mathrm{ml}$. The mean value of serum PTH was within the normal range (Table 2).

\section{Dietary changes during intervention}

The semi-skimmed milk supplementation resulted in an increase in energy intake that was associated with a significant

Table 1. Baseline characteristics of the thirty postmenopausal women (Mean values and standard deviations)

\begin{tabular}{lcc}
\hline & Mean & SD \\
\hline Age (years) & 59.5 & 3.3 \\
Years since menopause (years) & 9.2 & 3.2 \\
Standing height (cm) & 162.4 & 6.8 \\
Body weight (kg) & 62.1 & 7.5 \\
BMI (kg/m ${ }^{2}$ ) & 23.7 & 3.4 \\
Plasma FSH (IU/I) & 95.8 & 26.0 \\
Lumbar spine aBMD (T-score) $_{\text {Femoral neck aBMD (T-score) }}$ & -1.10 & 0.98 \\
Physical activity (score) & -0.88 & 0.71 \\
\end{tabular}

aBMD, areal bone mineral density; FSH, follicle-stimulating hormone.
Table 2. Blood biochemical variables determined at the end of the 4-week adaptation period*

(Mean values and standard deviations)

\begin{tabular}{|c|c|c|}
\hline & Mean & SD \\
\hline Calcium (mmol/l) & $2 \cdot 47$ & 0.07 \\
\hline Inorganic phosphate $(\mathrm{mmol} / \mathrm{l})$ & $1 \cdot 18$ & $0 \cdot 12$ \\
\hline Creatinine $(\mu \mathrm{mol} / \mathrm{l})$ & $66 \cdot 9$ & $6 \cdot 6$ \\
\hline 25-Hydroxyvitamin D (ng/ml) & $33 \cdot 8$ & $4 \cdot 4$ \\
\hline PTH $(\mathrm{pg} / \mathrm{ml})$ & $40 \cdot 4$ & $10 \cdot 5$ \\
\hline CTX (pmol/l) & 4207 & 1848 \\
\hline PINP (ng/ml) & $62 \cdot 7$ & $26 \cdot 1$ \\
\hline Osteocalcin (ng/ml) & $30 \cdot 9$ & $12 \cdot 0$ \\
\hline Bone alkaline phosphatase $(\mu \mathrm{g} / \mathrm{ml})$ & $12 \cdot 0$ & $4 \cdot 1$ \\
\hline IGF I (ng/ml) & $153 \cdot 3$ & $48 \cdot 2$ \\
\hline
\end{tabular}

CTX, crosslinked telopeptide of type I collagen; IGF, insulin-like growth factor; PINP, propeptide of type I procollagen; PTH, parathyroid hormone.

${ }^{*}$ For details of procedures, see Materials and methods.

increase of $16 \%$ in total protein intake as well as in the percentage of protein per energy intake (Table 3). Neither the carbohydrate nor lipid density were significantly altered by the semi-skimmed milk supplementation (Table 3). Calcium, inorganic phosphate, potassium and magnesium intakes significantly increased by $93,38,25$ and $13 \%$, respectively, while sodium intake remained virtually constant during the two experimental periods of 6 weeks (Table 3).

Body weight and consequently BMI were not influenced by the semi-skimmed milk supplementation. In this regard, the $500 \mathrm{ml} \mathrm{milk} / \mathrm{d}$ provided an additional intake of $962 \mathrm{~kJ}$ $(230 \mathrm{kcal}), 16 \mathrm{~g}$ proteins, $8 \mathrm{~g}$ lipids and $23 \mathrm{~g}$ glucides. The data recorded in the dietary diary indicates, as compared to the period without milk, a daily increase of $339 \mathrm{~kJ}(81 \mathrm{kcal})$, $10.6 \mathrm{~g}$ proteins, $0.1 \mathrm{~g}$ lipids, $10.5 \mathrm{~g}$ glucides. Thus, on the average, the participants reduced their spontaneous intake by $623 \mathrm{~kJ}$ (962 to $339 \mathrm{~kJ}$; i.e. by $149 \mathrm{kcal}$ ( 230 to $81 \mathrm{kcal})$ ), $5.4 \mathrm{~g}$ proteins ( 16.0 to $10.6 \mathrm{~g}), 8 \mathrm{~g}$ lipids and $12.5 \mathrm{~g}$ glucides (23.0 to $10.5 \mathrm{~g})$. This reduction and consequently mild increase in daily energy intake (less than $5 \%$ ) can explain why we were unable to detect a significant gain in body weight by the end of the period of milk supplementation.

\section{Biochemical changes during intervention}

Several variables related to bone metabolism were significantly influenced by the milk supplementation with a reduction in blood PTH, CTX, PINP and osteocalcin (Table 4). Neither BAP nor IGF I was statistically altered (Table 4). Figure 2 illustrates the percentage difference between the two experimental periods of these six blood variables. An additional statistical analysis by both paired $t$ test and ANOVA for repeated measurements was made in order to test whether the order of the intervention may have influenced the results. This analysis did not provide evidence that the significant decrease observed in the whole cohort (groups A + B) for PTH, CTX, PINP and osteocalcin was influenced by the order of the 6-week intervention periods, with milk supplementation during the first and second period in group A and B, respectively (data not shown).

Of note is that the mean absolute values of PTH, CTX, PINP and osteocalcin by the end of the adaptation period during 
Table 3. Nutritional variables during the period without and with milk supplementation* (Mean values and standard deviations)

\begin{tabular}{|c|c|c|c|c|c|c|}
\hline & \multicolumn{2}{|c|}{$\begin{array}{l}\text { Period without milk } \\
\text { supplementation }\end{array}$} & \multicolumn{2}{|c|}{$\begin{array}{l}\text { Period with milk } \\
\text { supplementation }\end{array}$} & \multirow[b]{2}{*}{ Difference } & \multirow[b]{2}{*}{$P \dagger$} \\
\hline & Mean & SD & Mean & SD & & \\
\hline Energy (kJ/d) & 7088 & 1172 & 7427 & 1506 & +339 & NS \\
\hline Energy $(\mathrm{kccl} / \mathrm{d})$ & 1694 & 280 & 1775 & 360 & +81 & NS \\
\hline Protein $(\mathrm{g} / \mathrm{d})$ & 68.3 & 14.9 & 78.9 & $16 \cdot 5$ & $+10 \cdot 6$ & $<0.0001$ \\
\hline Protein (\% energy) & $16 \cdot 7$ & 2.9 & 18.5 & 3.1 & +1.8 & 0.0011 \\
\hline Carbohydrates (\% energy) & $46 \cdot 3$ & $7 \cdot 0$ & 46.5 & $6 \cdot 3$ & +0.17 & NS \\
\hline Lipids (\% energy) & 37.0 & 6.0 & $35 \cdot 0$ & $5 \cdot 3$ & -1.95 & NS \\
\hline Calcium (mg/d) & 572 & 107 & 1105 & 143 & +533 & $<0.0001$ \\
\hline Phosphorus (mg/d) & 920 & 173 & 1272 & 230 & +352 & $<0.0001$ \\
\hline Sodium $(\mathrm{mg} / \mathrm{d})$ & 2147 & 645 & 2158 & 474 & +11 & NS \\
\hline Potassium (mg/d) & 2560 & 567 & 3200 & 552 & +567 & $<0.0001$ \\
\hline Magnesium (mg/d) & 234 & 56 & 264 & 52 & +31 & 0.0025 \\
\hline
\end{tabular}

${ }^{*}$ For details of procedures, see Materials and methods.

$\dagger P$ values are computed by paired $t$ test between the period with and without milk supplementation.

which the subjects consumed $250 \mathrm{ml}$ milk/d were intermediary (Table 2) between those recorded by the end of the period without and with a milk supplementatin of $500 \mathrm{ml} / \mathrm{d}$ (Table 4).

Among the urinary variables, the $24 \mathrm{~h}$ urine excretion was significantly elevated for inorganic phosphate $(+3.3 \mathrm{mmol} / \mathrm{d}$, $P=0.019)$ and potassium $(+12.1 \mathrm{mmol} / \mathrm{d}, P=0.0109)$, but not for calcium $(+0.14, P=0.633)$ during the milk-supplemented period. Neither TRCaI nor TmPi was significantly modified by the intervention, nor BRI (Table 5).

\section{Discussion}

There has been a renewed interest in non-pharmacological recommendation for attenuating bone loss in postmenopausal women. This stems from doubt raised by results obtained in large studies about adverse effects of hormonal replacement therapy with increased risk of CVD and breast cancer ${ }^{(12)}$. Furthermore, none of the other pharmacological agents such as bisphosphonates, the selective oestrogens receptor modulator raloxifene, strontium ranelate and $\mathrm{PTH}$ is recommended by national and international drug regulatory authorities to be used in the primary prevention of postmenopausal osteoporosis; their use in primary prevention being limited to women at high risk of experiencing, in a relatively short time, fragility fractures. For these various reasons only supplements of calcium and vitamin D are often prescribed. However, their efficacy is limited, particularly because of the difficulty in maintaining a satisfactory compliance in postmenopausal women not at increased risk of osteoporosis ${ }^{(22)}$.

The present study indicates that milk supplementation given to postmenopausal women with mean age slightly below 60 years and aBMD values either normal in the femoral neck (T-score -0.88 ) or at the upper limit of the osteopaenic range in the spine $(\mathrm{T} \text {-score }-1 \cdot 10)^{(35)}$ results in bone remodelling inhibition. Without milk supplementation the average of the serum bone resorption marker CTX was above the premenopausal reference values. With milk supplementation, the $14 \%$ fall in serum CTX was not only statistically significant

Table 4. Blood biochemical variables determined at the end of the 6-week period without and with milk supplementation* (Mean values and standard deviations)

\begin{tabular}{|c|c|c|c|c|c|c|}
\hline & \multicolumn{2}{|c|}{$\begin{array}{l}\text { Period without milk } \\
\text { supplementation }\end{array}$} & \multicolumn{2}{|c|}{$\begin{array}{l}\text { Period with milk } \\
\text { supplementation }\end{array}$} & \multirow[b]{2}{*}{ Difference } & \multirow[b]{2}{*}{$P \dagger$} \\
\hline & Mean & SD & Mean & SD & & \\
\hline Calcium (mmol/l) & $2 \cdot 32$ & 0.08 & $2 \cdot 32$ & 0.11 & 0 & - \\
\hline Inorganic phosphate (mmol/l) & $1 \cdot 25$ & 0.14 & $1 \cdot 22$ & 0.15 & -0.03 & NS \\
\hline Creatinine $(\mu \mathrm{mol} / \mathrm{l})$ & $66 \cdot 6$ & $7 \cdot 6$ & $67 \cdot 2$ & $7 \cdot 3$ & +0.6 & NS \\
\hline Proteins $(\mathrm{g} / \mathrm{l})$ & $68 \cdot 3$ & 3.5 & $69 \cdot 8$ & $3 \cdot 1$ & +1.5 & NS \\
\hline 25-Hydroxyvitamin D (ng/ml) & $29 \cdot 0$ & $4 \cdot 7$ & $28 \cdot 8$ & $5 \cdot 1$ & -0.2 & NS \\
\hline PTH (pg/ml) & 43.0 & $10 \cdot 8$ & $39 \cdot 8$ & $10 \cdot 8$ & $-3 \cdot 2$ & 0.0054 \\
\hline CTX (pmol/l) & 4445 & 1909 & 3821 & 1749 & -624 & 0.0001 \\
\hline PINP (ng/ml) & 64.9 & $24 \cdot 3$ & 59.5 & $21 \cdot 8$ & $-5 \cdot 5$ & 0.0092 \\
\hline Osteocalcin (ng/ml) & 31.5 & $13 \cdot 2$ & $28 \cdot 7$ & $10 \cdot 6$ & $-2 \cdot 8$ & 0.0014 \\
\hline Bone alkaline phosphatase $(\mu \mathrm{g} / \mathrm{ml})$ & $12 \cdot 2$ & $3 \cdot 6$ & $12 \cdot 2$ & 3.7 & 0 & - \\
\hline IGF I (ng/ml) & $157 \cdot 3$ & $40 \cdot 2$ & $164 \cdot 0$ & $42 \cdot 5$ & $+6 \cdot 7$ & NS \\
\hline
\end{tabular}

CTX, crosslinked telopeptide of type I collagen; IGF, insulin-like growth factor; PINP, propeptide of type I procollagen; PTH, parathyroid hormone.

${ }^{*}$ For details of procedures, see Materials and methods.

† $P$ values are computed by paired $t$ test between the period with and without milk supplementation. 


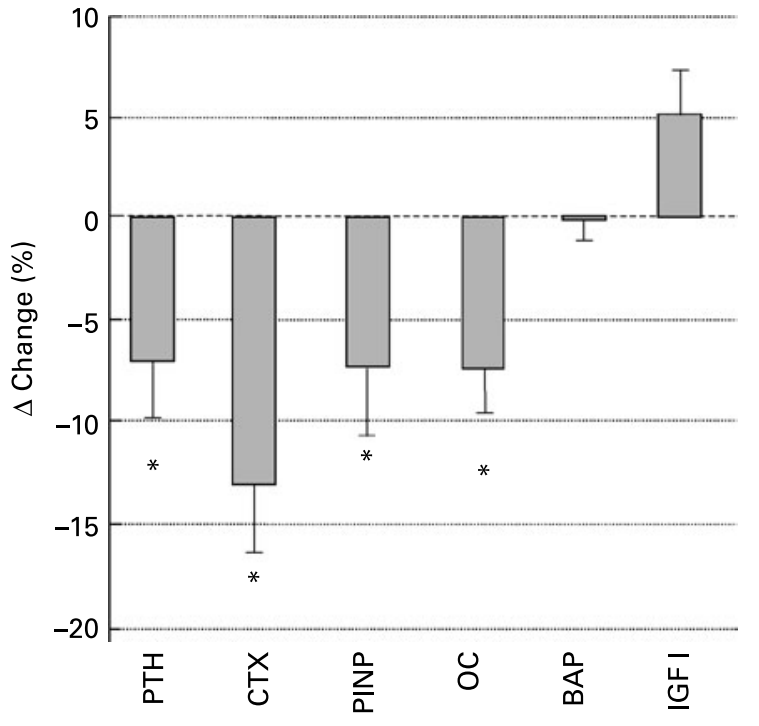

Fig. 2. Differences in percentage between the period without and with milk supplementation. Values are means with their standard errors depicted by vertical bars. Mean values were significantly different from zero: ${ }^{\star} P=0.0054$, $0.0010,0.0092,0.0014$, for parathyroid hormone (PTH); crosslinked telopeptide of type I collagen (CTX), propeptide of type I procollagen (PINP) and osteocalcin $(\mathrm{OC})$, respectively. The corresponding absolute values are presented in Table 4. BAP, bone alkaline phosphatase; IGF, insulin-like growth factor.

but also appears to be biologically meaningful. Indeed, the mean absolute value of serum CTX was close to the upper limit of the reference range established from blood samples of healthy premenopausal women as determined in the same laboratory by one co-investigator of the present trial (J.-C. S.).

Other markers of bone remodelling that reflect bone formation such as PINP and osteocalcin fell significantly but somewhat less than the marker of bone resorption, while no variation was observed in serum BAP. Osteocalcin, PINP and BAP reflect different stages of the osteoblastogenesis, i.e. the phases of proliferation, matrix maturation and mineralization. The reason why BAP was not affected in contrast to previous studies with milk $^{(45)}$ or high calcium mineral water $^{(46)}$ supplementation does not appear to be due to the cross-over study design. Indeed, BAP was not influenced whether milk supplemention was given during the first (group A) or the second (group B) period of 6 weeks.
Interestingly enough, the data are compatible with a milk dose response since the mean values of PTH, CTX, PINP and osteocalcin fell progressively down from no supplementation to 250 and $500 \mathrm{ml} / \mathrm{d}$ (Tables 2 and 4).

The pattern of biochemical markers of bone remodelling we observed recalls that recorded during the early phase of interventions using pharmaceutical anti-resorbing agents, such as oestrogens, bisphosphonate or raloxifene. It suggests that the foregoing reported milk intervention positively uncoupled the two processes of bone remodelling.

Overall, the present results are consistent with reported effects of calcium supplementation, taken either as isolated calcium salts, mineral water ${ }^{(24,33,47,48)}$ or milk ${ }^{(45,49)}$, on bone remodelling markers of postmenopausal women. However, these trials were conducted in cohorts including, at least in part, older postmenopausal women who were therefore at higher risk of osteoporosis $^{(24,33,47,48)}$. Indeed, besides the decline in aBMD, advancing age is an additional independent factor increasing the risk of fragility fractures ${ }^{(35)}$. Thus, for a given T-score of $-1 \cdot 0$, the estimated 10 -year risk for experiencing a fragility fracture is twice as high at 70-75 than at 50-55 years of age ${ }^{(50)}$. Therefore, in the clinical setting, the decision for prescribing pharmaceutical agents ${ }^{(4,51)}$ should be determined not only by the osteodensitometry value ${ }^{(52)}$ but also by the identification of risk factors among which age ${ }^{(35)}$, previous fracture ${ }^{(53)}$ and $\mathrm{BMI}^{(3)}$ have been clearly identified as of substantial importance in large-scale epidemiological studies.

The present study indicates that in relatively early postmenopausal years milk supplementation can efficiently slow down the rate of bone remodelling. The present observation sustains the notion that in postmenopausal women with femoral neck and lumbar spine aBMD values still within the normal range or in the upper part of the osteopaenic/low bone mass range ${ }^{(35)}$, and without any major detectable risk factor, preventive measures for bone loss resulting from oestrogen deficiency should be centred on lifestyle factors ${ }^{(54)}$. The present study brings biochemical support to this notion that is recommended by several national and international health institutions.

The inhibition of biochemical markers of bone remodelling probably resulted from the observed concomitant reduction in the serum level of PTH which, in turn, was probably mediated by the increased calcium intake. In addition, the milk-induced increment in protein intake may also have contributed to the reduction in the circulating level of PTH. Indeed, it has been

Table 5. Calcium and inorganic phosphate fluxes, and urinary electrolyte excretion*

(Mean values and standard deviations)

\begin{tabular}{|c|c|c|c|c|c|c|}
\hline & \multicolumn{2}{|c|}{$\begin{array}{l}\text { Period without milk } \\
\text { supplementation }\end{array}$} & \multicolumn{2}{|c|}{$\begin{array}{l}\text { Period with milk } \\
\text { supplementation }\end{array}$} & \multirow[b]{2}{*}{ Difference } & \multirow[b]{2}{*}{$P \dagger$} \\
\hline & Mean & SD & Mean & SD & & \\
\hline Urine calcium (mmol/24 h) & $4 \cdot 0$ & 1.9 & $4 \cdot 1$ & $2 \cdot 0$ & +0.1 & NS \\
\hline Urine inorganic phosphate (mmol/24 h) & $24 \cdot 4$ & $7 \cdot 7$ & $27 \cdot 8$ & $7 \cdot 0$ & $+3 \cdot 3$ & 0.0195 \\
\hline TRCal (mmol/l GFR) & $2 \cdot 64$ & 0.15 & $2 \cdot 62$ & 0.14 & -0.02 & NS \\
\hline $\mathrm{TmPi}(\mathrm{mmol} / \mathrm{l} \mathrm{GFR})$ & $1 \cdot 21$ & 0.17 & $1 \cdot 19$ & 0.23 & -0.02 & NS \\
\hline $\mathrm{BRI}$ (mmol Ca/mmol creatinine) & 0.29 & 0.16 & 0.30 & 0.16 & +0.01 & NS \\
\hline Urine sodium (mmol/24 h) & $122 \cdot 6$ & $39 \cdot 7$ & $122 \cdot 0$ & $47 \cdot 0$ & -0.6 & NS \\
\hline Urine potassium (mmol/24 h) & $60 \cdot 5$ & $18 \cdot 4$ & $72 \cdot 7$ & $23 \cdot 2$ & $+12 \cdot 1$ & 0.011 \\
\hline
\end{tabular}

BRI, net calcium bone resorption index; GFR, glomerular filtration rate; TmPi, tubular inorganic phosphate reabsorption capacity; TRCal, renal tubular calcium reabsorption index. ${ }^{*}$ For details of procedures, see Materials and methods.

$\dagger P$ values are computed by paired $t$ test between the period with and without milk supplementation. 
demonstrated that independently of any change in calcium consumption, increasing protein intake enhances intestinal calcium absorption capacity while reducing the serum level of $\mathrm{PTH}^{(55)}$. This effect could explain the fact that increasing both calcium and protein intakes can exert a positive impact on bone integrity. Furthermore, data suggest that these two nutrients may synergistically interact on calcium economy and bone metabolism ${ }^{(56-58)}$. In keeping with this notion, a positive effect of milk basic protein on lumbar spine aBMD of healthy postmenopausal women was associated with a reduction in urinary bone resorption marker without concomitant decrease in serum osteocalcin ${ }^{(59)}$.

All enrolled subjects remained compliant to the prescribed milk consumption. This maximal degree of both adherence and persistence during the 6-week period of milk supplementation reflects the good acceptability of this dairy product in this cohort of early postmenopausal women.

Several limitations of the reported trial have to be mentioned. A first limitation is the short time length of the study. It remains uncertain that both the reduced PTH level and bone turnover rate with greater inhibition in markers of bone resorption than formation will be maintained in the long term, eventually resulting in a substantial bone loss attenuation.

Second, the magnitude of the reduction in markers of bone resorption at the end of the milk supplementation was less than with therapeutic doses of strong inhibitors of bone resorption such as bisphosphonates ${ }^{(1,60)}$. However, it was close to that observed during the first months following the intervention onset with other inhibitors of bone resorption, such as low doses of oestrogens, raloxifene or strontium ranelate ${ }^{(61-63)}$. Nevertheless, with these compounds the reduced risk of experiencing new vertebral fractures ${ }^{(12,64,65)}$ was similar to that recorded under therapy with bisphosphonates such as alendronate or risedronate ${ }^{(65,66)}$

Third, the good tolerability to the supplementation observed in the present cohort can be due in part to a biased selection of enrolled subjects who were volunteers for the study and therefore had no particular dislike for milk. Therefore, one may expect a reduced percentage of postmenopausal women ready to step in and then to adhere and persist to drink daily half a litre of semi-skimmed milk. Nevertheless, more varying regimens providing an equivalent amount of calcium and proteins obtained from other dairy products could exert a similar positive impact on bone metabolism.

\section{Conclusion}

A 6-week period of milk supplementation leading to a mean increase in calcium intake from 572 to $1105 \mathrm{mg} / \mathrm{d}$ and of protein intake from 68 to $79 \mathrm{~g} / \mathrm{d}$ induced a significant decrease in several biochemical variables, a response compatible with a reduction of bone turnover. This nutritional approach, meant to alleviate the acceleration in bone remodelling, may be a valuable alternative to pharmaceutical therapy in postmenopausal women not at increased risk of osteoporosis.

\section{Acknowledgements}

We gratefully thank Mrs Paulette Rousset for efficiently contributing to a substantial part of the biochemical analysis. The study was funded by the Centre de Recherche et d'Information
Nutritionnelles, Paris, France. M.-C. B. is a part-time employee of the Centre de Recherche et d'Information Nutritionnelles. None of the authors has potential conflict of interest relevant to the data reported in this paper. J.-P. B., M. B.-B., M.-C. B. and J.-C. S. were responsible for the conception of the study, data analysis and interpretation. M. B.-B., Y. B., F. M.-L. and V. B. were responsible for organizing, supervising all practical aspects of the study and for the data programming. J.-C. S. was responsible of the determinations of all bone and calcium metabolism-related biochemical blood and urine variables. J.-P. B. was responsible for writing the manuscript. All authors were responsible for critically revising the manuscript.

\section{References}

1. Hannon RA \& Eastell R (2003) Biochemical markers of bone turnover and fracture prediction. J Br Menopause Soc 9, 10-15.

2. Garnero P \& Delmas PD (2004) Contribution of bone mineral density and bone turnover markers to the estimation of risk of osteoporotic fracture in postmenopausal women. J Musculoskelet Neuronal Interact 4, 50-63.

3. De Laet C, Kanis JA, Oden A, et al. (2005) Body mass index as a predictor of fracture risk: a meta-analysis. Osteoporos Int 16, $1330-1338$.

4. Kanis JA, Borgstrom F, Zethraeus N, Johnell O, Oden A \& Jonsson B (2005) Intervention thresholds for osteoporosis in the UK. Bone 36, 22-32.

5. Borgstrom F, Johnell O, Kanis JA, Jonsson B \& Rehnberg C (2006) At what hip fracture risk is it cost-effective to treat? International intervention thresholds for the treatment of osteoporosis. Osteoporos Int 17, 1459-1471.

6. Heikkinen J, Vaheri R \& Timonen U (2006) A 10-year followup of postmenopausal women on long-term continuous combined hormone replacement therapy: update of safety and quality-of-life findings. J Br Menopause Soc 12, 115-125.

7. Nelson HD, Humphrey LL, Nygren P, Teutsch SM \& Allan JD (2002) Postmenopausal hormone replacement therapy: scientific review. JAMA 288, 872-881.

8. Reed SD, Newton KM \& Lacroix AZ (2004) Indications for hormone therapy: the post-Women's Health Initiative era. Endocrinol Metab Clin North Am 33, 691-715.

9. Whitehead M \& Farmer R (2004) The million women study: a critique. Endocrine 24, 187-193.

10. NIH Consensus Conference (2005) NIH State-of-the-Science Conference Statement on management of menopause-related symptoms. NIH Consensus State-of-the-Science Statements 22, $1-38$.

11. Stevenson JC (2006) HRT, osteoporosis and regulatory authorities Quis custodiet ipsos custodes? Human Reprod 21, 1668-1671.

12. Rossouw JE, Anderson GL, Prentice RL, et al. (2002) Risks and benefits of estrogen plus progestin in healthy postmenopausal women: principal results from the Women's Health Initiative randomized controlled trial. JAMA 288, 321-333.

13. Udell JA, Fischer MA, Brookhart MA, Solomon DH \& Choudhry NK (2006) Effect of the Women's Health Initiative on osteoporosis therapy and expenditure in Medicaid. J Bone Miner Res 21, 765-771.

14. Usher C, Teeling M, Bennett K \& Feely J (2006) Effect of clinical trial publicity on HRT prescribing in Ireland. Eur J Clin Pharmacol 62, 307-310.

15. Guay MP, Dragomir A, Pilon D, Moride Y \& Perreault S (2007) Changes in pattern of use, clinical characteristics and persistence rate of hormone replacement therapy among 
postmenopausal women after the WHI publication. Pharmacoepidemiol Drug Safety 16, 17-27.

16. Chapuy MC, Arlot ME, Duboeuf F, et al. (1992) Vitamin D3 and calcium to prevent hip fractures in the elderly women. $N$ Engl J Med 327, 1637-1642.

17. Chevalley T, Rizzoli R, Nydegger V, et al. (1994) Effects of calcium supplements on femoral bone mineral density and vertebral fracture rate in vitamin-D-replete elderly patients. Osteoporos Int 4, 245-252.

18. Recker RR, Hinders S, Davies KM, et al. (1996) Correcting calcium nutritional deficiency prevents spine fractures in elderly women. J Bone Miner Res 11, 1961-1966.

19. Dawson-Hughes B, Harris SS, Krall EA \& Dallal GE (1997) Effect of calcium and vitamin D supplementation on bone density in men and women 65 years of age or older. $N$ Engl $\mathrm{J} \mathrm{Med}$ 337, 670-676.

20. Shea B, Wells G, Cranney A, et al. (2002) Meta-analyses of therapies for postmenopausal osteoporosis. VII. Meta-analysis of calcium supplementation for the prevention of postmenopausal osteoporosis. Endocr Rev 23, 552-559.

21. Boonen S, Bischoff-Ferrari HA, Cooper C, et al. (2006) Addressing the musculoskeletal components of fracture risk with calcium and vitamin D: a review of the evidence. Calcif Tissue Int 78, 257-270.

22. Rossini M, Bianchi G, Di Munno O, et al. (2006) Determinants of adherence to osteoporosis treatment in clinical practice. Osteoporos Int 17, 914-921.

23. Downey TW, Foltz SH, Boccuzzi SJ, Omar MA \& Kahler KH (2006) Adherence and persistence associated with the pharmacologic treatment of osteoporosis in a managed care setting. South Med J 99, 570-575.

24. Boonen S, Rizzoli R, Meunier PJ, et al. (2004) The need for clinical guidance in the use of calcium and vitamin D in the management of osteoporosis: a consensus report. Osteoporos Int 15, 511-519.

25. Bonjour JP, Schurch MA, Chevalley T, Ammann P \& Rizzoli R (1997) Protein intake, IGF-1 and osteoporosis. Osteoporos Int 7, Suppl. 3, S36-S42.

26. Munger RG, Cerhan JR \& Chiu BC (1999) Prospective study of dietary protein intake and risk of hip fracture in postmenopausal women. Am J Clin Nutr 69, 147-152.

27. Hannan MT, Tucker KL, Dawson-Hughes B, Cupples LA, Felson DT \& Kiel DP (2000) Effect of dietary protein on bone loss in elderly men and women: the Framingham Osteoporosis Study. J Bone Miner Res 15, 2504-2512.

28. Bonjour JP (2005) Dietary protein: an essential nutrient for bone health. J Am Coll Nutr 24, Suppl., 526S-536S.

29. Rogers A, Hannon RA \& Eastell R (2000) Biochemical markers as predictors of rates of bone loss after menopause. $J$ Bone Miner Res 15, 1398-1404.

30. Chapurlat RD, Garnero P, Breart G, Meunier PJ \& Delmas PD (2000) Serum type I collagen breakdown product (serum CTX) predicts hip fracture risk in elderly women: the EPIDOS study. Bone 27, 283-286.

31. Bruyere O, Collette J, Delmas P, et al. (2003) Interest of biochemical markers of bone turnover for long-term prediction of new vertebral fracture in postmenopausal osteoporotic women. Maturitas 44, 259-265.

32. Ravn P, Thompson DE, Ross PD \& Christiansen C (2003) Biochemical markers for prediction of 4-year response in bone mass during bisphosphonate treatment for prevention of postmenopausal osteoporosis. Bone 33, 150-158.

33. Grados F, Brazier M, Kamel S, et al. (2003) Prediction of bone mass density variation by bone remodeling markers in postmenopausal women with vitamin D insufficiency treated with calcium and vitamin D supplementation. J Clin Endocrinol Metab 88, 5175-5179.
34. Bauer DC, Black DM, Garnero P, et al. (2004) Change in bone turnover and hip, non-spine, and vertebral fracture in alendronate-treated women: the fracture intervention trial. $J$ Bone Miner Res 19, 1250-1258.

35. World Health Organization (1994) Assessment of Fracture Risk and its Application to Screening for Postmenopausal Osteoporosis. Report of a WHO Study Group. WHO Technical Report Series no. 843. Geneva: WHO.

36. Baecke JA, Burema J \& Frijters JE (1982) A short questionnaire for the measurement of habitual physical activity in epidemiological studies. Am J Clin Nutr 36, 936-942.

37. Favier JC, Ireland-Ripert J, Toque C \& Feinberg M (1995) Répertoire Général des Aliments. Table de Composition, 2nd ed. Paris: INRA.

38. Brandolini M, Gueguen L, Boirie Y, Rousset P, Bertiere MC \& Beaufrere B (2005) Higher calcium urinary loss induced by a calcium sulphate-rich mineral water intake than by milk in young women. Br J Nutr 93, 225-231.

39. Gascoin-Lachambre G, Trivin C, Brauner R \& Souberbielle JC (2007) Serum procollagen type 1 amino-terminal propeptide (P1NP) as an early predictor of the growth response to growth hormone treatment: comparison of intrauterine growth retardation and idiopathic short stature. Growth Horm IGF Res 17, 194-200.

40. Hollis BW, Kamerud JQ, Selvaag SR, Lorenz JD \& Napoli JL (1993) Determination of vitamin D status by radioimmunoassay with an ${ }^{125}$ I-labeled tracer. Clin Chem 39, 529-533.

41. Dawson-Hughes B, Heaney RP, Holick MF, Lips P, Meunier PJ \& Vieth R (2005) Estimates of optimal vitamin D status. Osteoporos Int 16, 713-716.

42. Walton RJ \& Bijvoet OL (1977) A simple slide-rule method for the assessment of renal tubular reaborption of phosphate in man. Clin Chim Acta 81, 273-276.

43. Buchs B, Rizzoli R \& Bonjour JP (1991) Evaluation of bone resorption and renal tubular reabsorption of calcium and phosphate in malignant and nonmalignant hypercalcemia. Bone $\mathbf{1 2}$, $47-56$.

44. Bonjour JP, Philippe J, Guelpa G, et al. (1988) Bone and renal components in hypercalcemia of malignancy and responses to a single infusion of clodronate. Bone 9, 123-130.

45. Heaney RP, McCarron DA, Dawson-Hughes B, et al. (1999) Dietary changes favorably affect bone remodeling in older adults. J Am Dietetic Assoc 99, 1228-1233.

46. Meunier PJ, Jenvrin C, Munoz F, de la Gueronniere V, Garnero P \& Menz M (2005) Consumption of a high calcium mineral water lowers biochemical indices of bone remodeling in postmenopausal women with low calcium intake. Osteoporos Int 16, $1203-1209$.

47. Storm D, Eslin R, Porter ES, et al. (1998) Calcium supplementation prevents seasonal bone loss and changes in biochemical markers of bone turnover in elderly New England women: a randomized placebo-controlled trial. J Clin Endocrinol Metab 83, 3817-3825.

48. Fardellone P, Brazier M, Kamel S, et al. (1998) Biochemical effects of calcium supplementation in postmenopausal women: influence of dietary calcium intake. Am J Clin Nutr 67, 1273-1278.

49. Palacios S, Castelo-Branco C, Cifuentes I, et al. (2005) Changes in bone turnover markers after calcium-enriched milk supplementation in healthy postmenopausal women: a randomized, double-blind, prospective clinical trial. Menopause 12, 63-68.

50. Kanis JA, Johnell O, Oden A, Dawson A, De Laet C \& Jonsson B (2001) Ten year probabilities of osteoporotic fractures according to BMD and diagnostic thresholds. Osteoporos Int 12, 989-995.

51. Kanis JA, Johnell O, Oden A, et al. (2005) Intervention thresholds for osteoporosis in men and women: a study based on data from Sweden. Osteoporos Int 16, 6-14. 
52. Johnell O, Kanis JA, Oden A, et al. (2005) Predictive value of BMD for hip and other fractures. $J$ Bone Miner Res 20, $1185-1194$.

53. Kanis JA, Johnell O, De Laet C, et al. (2004) A meta-analysis of previous fracture and subsequent fracture risk. Bone 35, $375-382$.

54. World Health Organization (2003) Prevention and Management of Osteoporosis. Report of a Scientific Group. WHO Technical Report Series no. 921. Geneva: WHO.

55. Kerstetter JE, O'Brien KO \& Insogna KL (2003) Dietary protein, calcium metabolism, and skeletal homeostasis revisited. Am J Clin Nutr 78, Suppl., 584S-592S.

56. Heaney RP (2001) The bone remodeling transient: interpreting interventions involving bone-related nutrients. Nutr Rev 59, 327-334.

57. Dawson-Hughes B \& Harris SS (2002) Calcium intake influences the association of protein intake with rates of bone loss in elderly men and women. Am J Clin Nutr 75, 773-779.

58. Heaney RP, Rafferty K \& Dowell MS (2002) Effect of yogurt on a urinary marker of bone resorption in postmenopausal women. J Am Dietetic Assoc 102, 1672-1674.

59. Aoe S, Koyama T, Toba Y, Itabashi A \& Takada Y (2005) A controlled trial of the effect of milk basic protein (MBP) supplementation on bone metabolism in healthy menopausal women. Osteoporos Int 16, 2123-2128.

60. Garnero P (2000) Markers of bone turnover for the prediction of fracture risk. Osteoporos Int 11, Suppl. 6, S55-S65.
61. Lindsay R, Gallagher JC, Kleerekoper M \& Pickar JH (2002) Effect of lower doses of conjugated equine estrogens with and without medroxyprogesterone acetate on bone in early postmenopausal women. JAMA 287, 2668-26676.

62. Delmas PD, Bjarnason NH, Mitlak BH, et al. (1997) Effects of raloxifene on bone mineral density, serum cholesterol concentrations, and uterine endometrium in postmenopausal women. $N$ Engl J Med 37, 1641-1647.

63. Meunier PJ, Roux C, Seeman E, et al. (2004) The effects of strontium ranelate on the risk of vertebral fracture in women with postmenopausal osteoporosis. $N$ Engl J Med 350, 459-468.

64. Ettinger B, Black DM, Mitlak BH, et al. (1999) Reduction of vertebral fracture risk in postmenopausal women with osteoporosis treated with raloxifene: results from a 3-year randomized clinical trial. Multiple Outcomes of Raloxifene Evaluation (MORE) Investigators. JAMA 282, 637-645.

65. Reginster J, Minne HW, Sorensen OH, et al. (2000) Randomized trial of the effects of risedronate on vertebral fractures in women with established postmenopausal osteoporosis. Vertebral Efficacy with Risedronate Therapy (VERT) Study Group. Osteoporos Int 11, 83-91.

66. Liberman UA, Weiss SR, Broll J, et al. (1995) Effect of oral alendronate on bone mineral density and the incidence of fractures in postmenopausal osteoporosis. The Alendronate Phase III Osteoporosis Treatment Study Group. N Engl J Med 333, $1437-1443$. 